\title{
The Presence of Agrobacterium tumefaciens Plasmid DNA in Crown Gall Tumour Cells
}

\author{
By ANN G. MATTHYSSE* AND ANNE J. STUMP \\ Department of Microbiology, Indiana University School of Medicine, \\ Indianapolis, Indiana 46202, U.S.A.
}

(Received 2 January 1975; revised 19 May 1975) $\dagger$

\section{SUMMARY}

DNA hybridization studies indicate the presence of DNA complementary to Agrobacterium tumefaciens plasmid in bacterium-free crown gall tumour cells. The amount of this DNA is estimated to be about $0.1 \%$ of the tumour cell DNA.

\section{INTRODUCTION}

Extracellular infections of wounded dicotyledonous plants by the Gram-negative bacterium, Agrobacterium tumefaciens (Smith and Townsend, Conn.) result in the transformation of normal plant cells to tumour cells. These crown gall tumour cells will continue to grow autonomously in the absence of the bacterium (Braun, 1943). Various mechanisms have been proposed for the induction of these tumours, including the transfer of genetic information (either as DNA or as RNA) from the bacterium to the plant cell (Srivastava, I965; Braun \& Wood, I966; Schilperoort et al. I967; Guille, Quetier \& Huguet, I968; Milo \& Srivastava, I969; Quetier, Huguet \& Guille, 1969; Schilperoort, van Sittert \& Schell, I973; Zaenen et al. 1974).

Direct evidence from nucleic acid hybridization studies for the presence of DNA complementary to bacterial DNA in bacterium-free crown gall tumour cells has been presented by some authors (Srivastava, 1965; Schilperoort et al. 1967; Milo \& Srivastava, 1969; Quetier et al. 1969). The estimated amount of DNA involved seems very large, between I and 9 bacterial genome-equivalents per plant cell (Quetier et al. I969; Schilperoort et al. 1973). However, there are also hybridization studies indicating the absence of such large amounts of DNA complementary to bacterial DNA in crown gall tumour cells (Chilton et al. 1974a, $b$; Eden et al. 1974; Drlica \& Kado, 1974).

The presence of plasmid DNA in A.tumefaciens and its correlation with the virulence of various strains (Van Larebeke et al. 1974; Zaenen et al. 1974) suggested that it would be of interest to examine the possible role of bacterial and plasmid DNA in tumour induction by using DNA:DNA hybridization studies.

\section{METHODS}

Media. Bacteria were grown in minimal salts medium containing $(\mathrm{g} / \mathrm{l}): \mathrm{NH}_{4} \mathrm{Cl}, 5 ; \mathrm{NH}_{4} \mathrm{NO}_{3}$, I; $\mathrm{Na}_{2} \mathrm{SO}_{4}, 2 ; \mathrm{K}_{2} \mathrm{HPO}_{4}, 3 ; \mathrm{KH}_{2} \mathrm{PO}_{4}, \mathrm{I} ; \mathrm{MgSO}_{4} .7 \mathrm{H}_{2} \mathrm{O}$, $0 . \mathrm{I}$, with $0.2 \%$ glucose and $50 \mu \mathrm{Ci}$ methyl $\left[{ }^{3} \mathrm{H}\right]$ thymidine or $10 \mu \mathrm{Ci}{ }^{32} \mathrm{PO}_{4} / \mathrm{ml}$ (Clowes \& Hayes, 1968). Plant tissue-

* Present address: Department of Botany, University of North Carolina, North Carolina 275I4, U.S.A.

$\uparrow$ Publication delayed at the request of the authors. 
culture cells of normal Vinca rosea were grown in White's medium (Wood \& Braun, I96I) supplemented with (mg/l): $\alpha$-naphthalene acetic acid, I; kinetin, 0.5; asparagine, 200; glutamine, 200; $m$-inositol, I00; AMP, I00; GMP, I00. Vinca rosea crown gall tumour cells were grown on unsupplemented White's medium. All cultures were grown at $25{ }^{\circ} \mathrm{C}$, with $14 \mathrm{~h}$ of light/day.

Organisms. Agrobacterium tumefaciens strain A6, normal Vinca rosed tissue-culture cells $(\mathrm{NV})$, and bacterium-free Vinca rosea crown gall tissue culture strains $\mathrm{V}_{\mathrm{A} 6}$ and $\mathrm{V}_{\mathrm{BP}}$ were obtained from Professor A. Braun.

Isolation of DNA. Plant-cell DNA was extracted by the method of Kirby (I957). Cells from cultures which had not yet reached the stationary phase of growth were frozen on dry ice and ground in $0.3 \mathrm{M}$-sodium trichloroacetate $\mathrm{pH} 6.5$ in a Waring blendor. The homogenate was filtered through two layers of cheesecloth and extracted with an equal volume of phenol. The aqueous layer was then mixed with an equal volume of 2-ethoxyethanol; the precipitate was redissolved in $0.3 \mathrm{M}$-sodium trichloracetate $\mathrm{pH} 6.5$ and reprecipitated three times. The precipitate was then dissolved in $\mathrm{H}_{2} \mathrm{O}$, and $4 \mathrm{~g}$ sodium acetate/ $\mathrm{I} 00 \mathrm{ml}$ were added and dissolved, followed by an equal volume of 2-ethoxyethanol. The precipitate was then dissolved in $0 . \mathrm{I} \times \mathrm{SSC}$ (saline sodium citrate, where I $\times$ SSC contains $0.15 \mathrm{M}$ $\mathrm{NaCl}$ and $0.015 \mathrm{M}$-trisodium citrate) and digested for $90 \mathrm{~min}$ at $37^{\circ} \mathrm{C}$ with RNAase A (Sigma; $20 \mu \mathrm{g} / \mathrm{ml}$, heated at $100{ }^{\circ} \mathrm{C}$ for $\mathrm{I} 0 \mathrm{~min}$ before use) followed by pronase (Calbiochem; $200 \mu \mathrm{g} / \mathrm{ml}$, self-digested for $90 \mathrm{~min}$ before use) for $\mathrm{I} 20 \mathrm{~min}$. The DNA was then purified by extraction with chloroform containing I00 $\mathrm{ml} n$-octanol/1. The extraction was repeated at least four times, and the DNA precipitated with 2 vol. of cold ethanol. The precipitate was redissolved in $0^{\cdot I} \times \mathrm{SSC}$. Purified DNA preparations in $0^{\cdot I} \times \mathrm{SSC}$ had $E_{260} / E_{280}$ ratios between $\mathrm{I} \cdot 70$ and $\mathrm{I} \cdot 85$. No RNA was detectable by examination of the supernatant from the base hydrolysis $\left(0.3 \mathrm{M}-\mathrm{KOH}, 18 \mathrm{~h}, 37^{\circ} \mathrm{C}\right)$ of $40 \mu \mathrm{g} \mathrm{DNA} / \mathrm{ml}$ for $E_{260}$.

Bacteria were lysed by using the freeze-thaw lysozyme technique (Kohler, Ron \& Davis, I966) followed by the addition of $0.1 \%$ sodium dodecyl sulphate. The lysate was extracted with chloroform-isoamyl alcohol (24: I, v/v) four times (Marmur, I96I). The aqueous layer was added to $2 \mathrm{vol}$. of cold ethanol and the DNA wound out of solution. The DNA was dissolved in $0 \cdot \mathrm{I} \times \mathrm{SSC}$ and digested for $90 \mathrm{~min}$ at $37^{\circ} \mathrm{C}$ with RNAase A (Sigma; $20 \mu \mathrm{g} /$ $\mathrm{ml}$, heated at $100{ }^{\circ} \mathrm{C}$ for Io $\mathrm{min}$ before use) followed by pronase (Calbiochem; $200 \mu \mathrm{g} / \mathrm{ml}$, self-digested for $90 \mathrm{~min}$ before use) for $\mathrm{I} 20 \mathrm{~min}$. The solution was extracted three times with chloroform and added to 2 vol. of cold ethanol. The DNA was wound out of solution and dissolved in $0 \cdot \mathrm{I} \times \mathrm{SSC}$. Purified DNA preparations in $0 \cdot \mathrm{I} \times \mathrm{SSC}$ had $E_{260} / E_{280}$ ratios between $\mathrm{I} \cdot 75$ and $\mathrm{I} \cdot 85$. No RNA was detectable by examination of the supernatant from the base hydrolysis $\left(0.3 \mathrm{M}-\mathrm{KOH}, \mathrm{I} 8 \mathrm{~h}, 37^{\circ} \mathrm{C}\right)$ of $400 \mu \mathrm{g} \mathrm{DNA} / \mathrm{ml}$ for radioactivity or $E_{260}$.

Bacterial-plasmid DNA was prepared from the supernatant of the salt precipitation of chromosomal DNA from bacteria lysed by using sodium dodecyl sulphate and lysozyme (Guerry, Le Blanc \& Falkow, 1973). The supernatant was diluted with an equal volume of 0.0 I M-tris-HCl-buffer $\mathrm{pH} 8.0$ and layered on a linear 5 to $20 \%$ sucrose gradient and centrifuged at $300000 \mathrm{~g}$ in an SW65 rotor for I h. Fractions were collected and those containing the plasmid peak (as determined by radioactivity) were pooled and dialysed against $0 \cdot$ I $\times$ SSC. Only a single band of radioactivity with an estimated molecular weight of $10^{8}$ was observed on these sucrose gradients. This band of plasmid DNA would include open-circular plasmid DNA and linear plasmid DNA, as well as any covalently-closed-circular plasmid DNA which was relaxed by the sodium dodecyl sulphate treatment. The plasmid DNA preparation was then digested with RNAase and pronase, and chloroform-extracted and ethanol-precipitated as described above for plant DNA. ${ }^{125}$ I-labelled DNA was prepared 
by using a modification of the technique of Prensky, Steffenson \& Hughes (1973) and purified by chromatography on hydroxyapatite. Radioactive DNA to be used in the liquid phase of filter-paper hybridization reactions and the plant and plasmid DNAs used in hybridization reactions in solution, were degraded to a molecular weight of approximately $2 \times 10^{5}$ by a limited depurination reaction (McConaughy \& McCarthy, 1967). The DNA was dissolved in $0 . \mathrm{I}$ M-sodium acetate $\mathrm{pH} 4.2$ and heated at $70^{\circ} \mathrm{C}$ for $33 \mathrm{~min}$. The $\mathrm{pH}$ of the solution was adjusted to 12 with $\mathrm{NaOH}$ and the solution heated at $50{ }^{\circ} \mathrm{C}$ for $10 \mathrm{~min}$. It was then dialysed against $\mathrm{I} \cdot 5 \times \mathrm{SSC}$.

${ }^{3} \mathrm{H}$-labelled adenovirus SA7 DNA was kindly provided by Dr J. P. Burnett. It was extracted and labelled by following the procedures of Burnett \& Harrington (1968) and Burnett et al. (1968). Radioactive bacterial DNA was prepared by growing the bacteria in minimal salts medium with 25 to $50 \mu \mathrm{Ci}$ methyl $\left[{ }^{3} \mathrm{H}\right]$ thymidine $/ \mathrm{ml}$ or Io $\mu \mathrm{Ci}{ }^{32} \mathrm{PO}_{4} / \mathrm{ml}$. The specific activities obtained ranged from $5 \times 10^{3}$ to $7 \times 10^{4}$ c.p.m. $/ \mu \mathrm{g}$ for ${ }^{3} \mathrm{H}-\mathrm{DNA}$ and from $\mathrm{I} \times 1 \mathrm{IO}^{3}$ to $8 \times 10^{3}$ c.p.m./ $\mu \mathrm{g}$ for ${ }^{32} \mathrm{PO}_{4}$-DNA.

DNA hybridization reactions. The filter-paper DNA hybridization technique of Denhardt (1966) was used. Double-stranded DNA was denatured by exposure to high $\mathrm{pH}$. It was then neutralized to $\mathrm{pH} 7$ and trapped on Millipore GS filter papers by filtration in $6 \times \mathrm{SSC}$, dried, and heated at $80^{\circ} \mathrm{C}$ under a vacuum for $2 \mathrm{~h}$. The filter papers were placed in pre-incubation medium [0.02\% (w/v) bovine serum albumin (Armour; fraction $\mathrm{V}$ ), $0.02 \%(w / v)$ Ficoll (Pharmacia; average mol. wt 400000) and $0.02 \%$ (w/v) polyvinylpyrrolidone (Sigma; average mol. wt 360000)] in $\mathrm{I} \cdot 5 \times \mathrm{SSC}$ at $67^{\circ} \mathrm{C}$ for 6 to $\mathrm{I} 2 \mathrm{~h}$ and then reacted with radioactive DNA in $3 \mathrm{ml} \mathrm{I} \cdot 5 \times \mathrm{SSC}$ at $67^{\circ} \mathrm{C}$ for $\mathrm{I} 8$ or more hours. The filter papers were removed, washed in $\mathrm{I} \times \mathrm{SSC}$, dried, and counted in a liquid scintillation counter. The melting temperature of the radioactive DNA hybrids was determined by removing the filter paper from the toluene scintillation fluid, washing it with toluene, drying it, placing it in $0.1 \times S S C$ at the desired temperature for 30 to $60 \mathrm{~min}$, washing it with $0 \cdot \mathrm{I} \times \mathrm{SSC}$, drying the filter paper, and recounting it.

Hybridization reactions in solution were carried out in $1 \cdot 5 \times \mathrm{SSC}$ at $67^{\circ} \mathrm{C}$. The DNA was denatured by exposure to high $\mathrm{pH}$. The DNA concentration in the reactions was kept constant at $150 \mu \mathrm{g} / \mathrm{ml}$ by adding calf-thymus DNA (Sigma; type V) or normal $V$. rosea DNA, both of which were degraded to a molecular weight of $2 \times 10^{5}$ by using the limited depurination reaction described above. Total radioactive DNA was measured by trichloroacetic acid (TCA) precipitation using bovine serum albumin as a carrier, followed by filtration on GF/A filters which were washed with ethanol and ether, dried, and counted in a liquid scintillation counter in toluene containing $5 \mathrm{~g}$ PPO and $0.3 \mathrm{~g}$ POPOP/l. Double-stranded radioactive DNA was measured by incubating the sample (Io $\mu \mathrm{g}$ or less) with 2 units of Neurospora crassa endonuclease (Miles Laboratories) in $\mathrm{I} \cdot 5 \times \mathrm{SSC}$ at $37^{\circ} \mathrm{C}$ for $30 \mathrm{~min}$ to degrade single-stranded DNA. The remaining double-stranded DNA was precipitated by TCA, collected by filtration on GF/A filters, and counted.

\section{RESULTS}

\section{Filter-paper hybridization reactions}

The results of filter-paper hybridization reactions are shown in Table I. The amount of bacterial DNA which hybridized with tumour-cell DNA was variable, depending on the preparation of bacterial DNA used. The range of values for bacterial DNA hybridized to $40 \mu \mathrm{g}$ of tumour-cell DNA was 0.5 to $15 \mathrm{ng}$ for all bacterial DNA preparations, and 2 to I $5 \mathrm{ng}$ for bacterial DNA from stationary-phase cultures. Each individual DNA preparation 


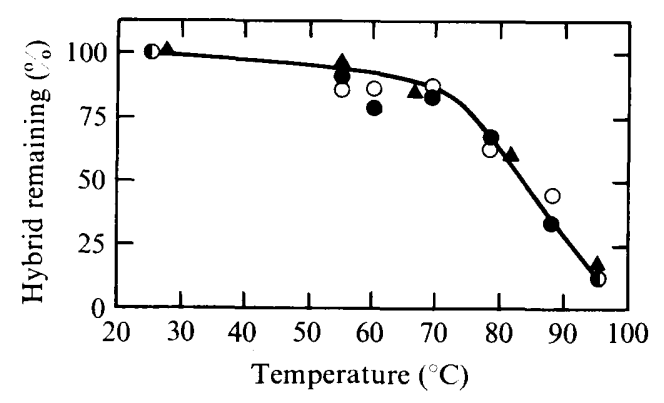

Fig. I

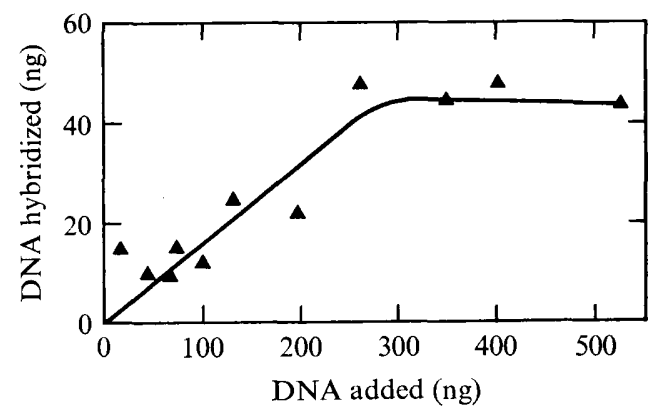

Fig. 2

Fig. I. Melting curves of hybridization reactions. The melting was carried out in $0.1 \times$ SSC. $\bigcirc$, Agrobacterium tumefaciens: $A$. tumefaciens hybrid; $\Theta, A$. tumefaciens: $V$. rosea tumour $\mathrm{v}_{\mathrm{A} 6}$ hybrid; $\boldsymbol{\Delta}$, A. tumefaciens plasmid DNA: $V$. rosea tumour $\mathrm{v}_{\mathrm{A} 6}$ hybrid.

Fig. 2. Hybridization of $V$. rosea $\mathrm{V}_{\mathrm{AB}}$ tumour DNA with increasing amounts of $A$. tumefaciens $\mathrm{A} 6$ plasmid DNA. The filter papers contained $40 \mu \mathrm{g}$ of $\mathrm{v}_{\mathbf{A} 6} \mathrm{DNA}$. The hydridization reaction was at $67^{\circ} \mathrm{C}$ in $1.5 \times \mathrm{SSC}$.

Table I. Filter-paper hybridizations

Radioactive DNA in solution

Stationary-phase $A$. tumefaciens A6 $(2 \mu \mathrm{g}) *$ Exponential-phase $A$. tumefaciens A6 $(2 \mu \mathrm{g}) *$ Plasmid from $A$. tumefaciens a6 $(0.02 \mu \mathrm{g}) \dagger$

\begin{tabular}{|c|c|c|}
\hline $\begin{array}{l}\text { Exponential-phase } \\
\text { A. tumefaciens A6 }\end{array}$ & $\begin{array}{l}\text { Normal } \\
V . \text { rosea }\end{array}$ & $\begin{array}{c}\text { Tumour } \\
V \text {. rosea } \mathrm{v}_{\mathrm{A} 6}\end{array}$ \\
\hline 327 & 0.7 & $4 \cdot 2$ \\
\hline 282 & 0.8 & 0.9 \\
\hline $8 \cdot 6$ & 0.0 & 15.7 \\
\hline
\end{tabular}

* Numbers are averages of at least ten reactions.

$\dagger$ The amount of plasmid DNA was calculated assuming the specific activity of plasmid DNA was the same as that of chromosomal DNA. Numbers are averages of five reactions.

gave consistent $( \pm 15 \%)$ results on duplicate experiments. We believe this variation to be due to variations in the amount of plasmid DNA contained in the bacterial DNA preparation since the percentage of plasmid DNA varies with the growth phase. In minimal salts medium the percentage of plasmid DNA is highest in stationary-phase cultures (Matthysse, unpublished observations). The hybridization of bacterial DNA to tumour-cell DNA was also highest with bacterial DNA from stationary-phase cultures. The hybridization of bacterial DNA with normal plant-cell DNA was too small to be significant with this technique, and all of this hybrid melted at a temperature below $55^{\circ} \mathrm{C}$ in $0 \cdot \mathrm{I} \times \mathrm{SSC}$. Similar data were obtained when ${ }^{125}$ I-labelled bacterial DNA was used in the hybridization reaction. The melting curves of such filter-paper hybrids between radioactive bacterial DNA and non-radioactive bacterial DNA or tumour-cell DNA are shown in Fig. I. Eighty-five \% of each hybrid melted at a temperature above $70^{\circ} \mathrm{C}$.

To determine whether plasmid DNA was indeed involved in this hybridization reaction between bacterial and tumour-cell DNA, purified plasmid DNA was prepared and used in the hybridization reaction. Although no plasmid DNA could be seen to hybridize to normalcell DNA, the plasmid DNA did hybridize to about $0.04 \%$ of tumour-cell DNA (Table I). The melting profile of this hybrid indicated that $80 \%$ of the hybrid was stable at $70{ }^{\circ} \mathrm{C}$ and melted between 75 and $85{ }^{\circ} \mathrm{C}$ (Fig. I). 
Increasing amounts of plasmid DNA were added to the hybridization reaction to obtain a saturation value for the amount of tumour-cell DNA complementary to plasmid DNA (Fig. 2). Approximately $0.1 \%$ of the tumour-cell DNA appeared to be complementary to bacterial-plasmid DNA.

Liquid hybridization reactions. To obtain another estimate of the amount of DNA complementary to bacterial DNA present in a tumour cell, hybridization reactions in solution were carried out using radioactive bacterial-plasmid DNA. Such DNA hybridization reactions are bimolecular reactions in which the concentrations of the two reacting complementary strands are equal. The extent of renaturation at any time $t$ can be expressed as

$$
\frac{C o}{C}=\frac{K_{2} C o t}{2}+\mathrm{I},
$$

where $C o$ is the total concentration of the renaturing sequences, $C$ the concentration of single-stranded sequences, and $K_{2}$ the second-order rate constant (Wetmur \& Davidson, 1968). If the original renaturing sequences are radioactive and an additional amount of non-radioactive DNA of the same sequences is added to the reaction mixture, then the rate of renaturation of the radioactive sequences will be increased, so that

$$
\frac{C o}{C}=\frac{K_{2} \operatorname{Co}(\mathrm{I}+r) t}{2}+\mathrm{I},
$$

where $C o$ and $C$ refer to the concentrations of total and single-stranded radioactive sequences respectively and $r$ is the ratio of non-radioactive sequences to the radioactive sequences (Sharp, Petersson \& Sambrook, 1974). If $\mathrm{Co} / C$ is plotted against $t$, in the presence and absence of the additional complementary DNA sequences, then the slope of the lines will be $K_{2} \mathrm{Co} / 2$ and $K_{2} \mathrm{Co}(\mathrm{I}+r) / 2$, respectively, and the ratio of the slopes will be $(\mathrm{I}+r)$. Thus the amount of tumour-cell DNA which is complementary to bacterial-plasmid DNA can be determined by measuring the rate of renaturation of a known concentration of radioactive bacterial-plasmid DNA in the absence and presence of a known concentration of tumourcell DNA.

To check this technique for determining the presence of small amounts of non-radioactive plasmid-DNA sequences, the renaturation of radioactive plasmid DNA was measured in the absence and presence of known amounts of non-radioactive plasmid DNA (Fig. 3). The addition of $\mathrm{I} \cdot \mathrm{I} \mu \mathrm{g}$ non-radioactive plasmid $\mathrm{DNA} / \mathrm{ml}$ to $\mathrm{I} \cdot \mathrm{I} \mu \mathrm{g}$ radioactive plasmid DNA $/ \mathrm{ml}$ increases the slope of the plot of $C o / C$ versus $t$ by $\mathrm{I} \cdot 95$. The predicted increase in slope would be $2 \cdot 0$. Thus the technique seems to be sensitive enough to be used to detect the presence of small amounts of plasmid-DNA sequences in tumour-cell DNA.

The results of such experiments are shown in Fig. $4 .{ }^{3} \mathrm{H}$-labelled adenovirus SA7 DNA was included in the reaction mixtures as a control for non-specific increases in the rate of hybridization. The presence of tumour-cell DNA did not affect the rate of renaturation of the adenovirus DNA but it did increase the rate of renaturation of plasmid DNA. The increase in the slope of the line for plasmid DNA renaturation in the presence of tumourcell DNA indicates that $0.2 \%$ of the tumour-cell DNA was complementary to plasmid DNA.

It is difficult to convert this number into an amount of DNA complementary to plasmid DNA per diploid plant-cell genome as many of the tissue culture cells are aneuploid (Matthysse, unpublished observations).

The $\mathrm{Cot}_{\mathrm{f}}$ for the adenovirus SA7 DNA under these conditions was 0.06 . The complexity of the SA7 DNA is $2 \cdot 2 \times 10^{7}$ (Burnett \& Harrington, 1968). Its expected Cot $_{\ddagger}$ (measured by 


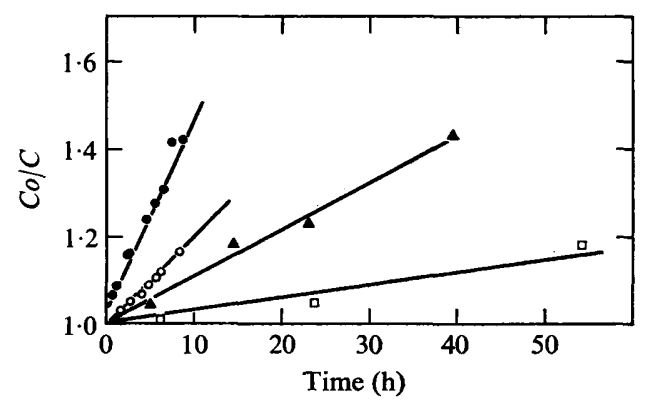

Fig. 3. Renaturation of $A$. tumefaciens A6 plasmid DNA. $\square$, Renaturation of $0.44 \mu \mathrm{g}$ radioactive plasmid DNA $/ \mathrm{ml}$, alone; $\boldsymbol{\Delta}$, renaturation of $\mathrm{I} \cdot \mathrm{I} \mu \mathrm{g}$ radioactive plasmid $\mathrm{DNA} / \mathrm{ml}$, alone; $O$, renaturation of $\mathrm{I} \cdot \mathrm{I} \mu \mathrm{g}$ radioactive plasmid DNA and $\mathrm{I} \cdot \mathrm{I} \mu \mathrm{g}$ non-radioactive plasmid DNA $/ \mathrm{ml}$; 0 , renaturation of $\mathrm{I} \cdot \mathrm{I} \mu \mathrm{g}$ radioactive plasmid DNA and $3 \cdot 3 \mu \mathrm{g}$ non-radioactive plasmid DNA $/ \mathrm{ml}$.

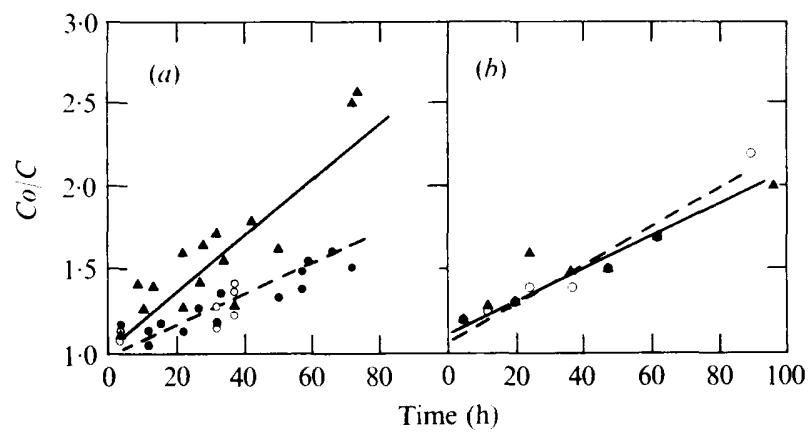

Fig. 4. Renaturation of $A$. tumefaciens A6 plasmid DNA and adenovirus SA7 DNA, with and without $V$. rosea $\mathrm{v}_{\mathrm{A} 6}$ tumour DNA. $\bigcirc, 0$, Renaturation of $(a)$ plasmid DNA, and $(b)$ SA7 DNA, in mixture $\mathrm{I} ; \boldsymbol{\Delta}$, renaturation of $(a)$ plasmid DNA, and $(b)$ SA7 DNA, in mixture 2. Mixture I contained $(\mu \mathrm{g} /$ $\mathrm{ml}$ ), in $1.5 \times \mathrm{SSC}:{ }^{32} \mathrm{P}$-labelled $A$. tumefaciens a6 plasmid DNA, 0.8; normal $V$. rosea $(\bullet)$ or calf thymus (O) DNA, 149; ${ }^{3} \mathrm{H}$-labelled adenovirus SA7 DNA, 0.043. Mixture 2 contained $(\mu \mathrm{g} / \mathrm{ml})$, in I.5 $\times$ SSC: ${ }^{32}$ P-labelled $A$. tumefaciens A6 plasmid DNA, 0.8; tumour $V$. rosea $\mathrm{V}_{\mathrm{A} 6} \mathrm{DNA},{ }^{4} 49 ;{ }^{3} \mathrm{H}-$ labelled adenovirus SA7 DNA, $0 \cdot 043$.

extinction which gives a larger $\mathrm{Cot}_{\mathrm{z}}$ value than does hydroxyapatite) would be 0.05 (Britten $\&$ Kohne, 1965). [Extinction measurements of $\mathrm{Cot}_{\frac{1}{2}}$ values are probably closer to the values obtained by single-stranded nuclease degradation, which is the procedure used here, than to hydroxyapatite $\mathrm{Cot}_{\mathrm{l}}$ measurements, since hydroxyapatite measures unpaired singlestranded tails of double-stranded hybrids as double-stranded (Britten \& Kohne, 1965).] The Cot $_{\frac{1}{\mathrm{t}}}$ for the plasmid DNA was 0.4 . If the complexity of the plasmid DNA is $\mathrm{I} \cdot \mathrm{I} \times 10^{8}$ (Zaenen et al. 1974), its expected Cot would be 0.4 (Britten \& Kohne, 1965).

\section{DISCUSSION}

The evidence presented above supports the hypothesis that $A$. tumefaciens induces tumours by transferring nucleic acid from the bacterium to the plant cell. The nucleic acid involved is apparently the bacterial-plasmid DNA. Earlier difficulties in reproducing results from various laboratories may have been due to variations in the amount of plasmid DNA contained in bacterial, and possibly plant, DNA preparations. The amount of DNA in a plant tumour cell complementary to plasmid DNA is estimated to be between $O \cdot I$ and 
$0.2 \%$ of the plant-cell DNA. The role of this plasmid DNA in transforming a normal cell to a tumour cell remains unknown.

We are grateful to Dr J. P. Burnett for preparing the ${ }^{125}$ I-labelled DNA, for the gift of the ${ }^{3} \mathrm{H}$-labelled adenovirus DNA, and for helpful discussions. We also thank Patricia Jemison for helping to extract DNA and D. Denny for help with the preliminary experiments. This research was supported by Public Health Service research grant No. CA I3253. A.J.S. thanks Indiana University School of Medicine for a summer fellowship.

\section{REFERENCES}

Burnett, J. P. \& Harrington, J. A. (1968). Simian adenovirus sa7 DNA: chemical, physical, and biological studies. Proceedings of the National Academy of Sciences of the United States of America 60, 1023-1029.

Burnett, J. P., Summers, A. O., Harrington, J. A. \& Dwyer, A. C. (1968). Production of highly labelled adenoviruses. Applied Microbiology 16, I245-1 250.

Braun, A. C. (1943). Studies on tumor inception in the crown-gall disease. American Journal of Botany 30, 674-677.

Braun, A. C. \& Wood, H. N. (1966). On the inhibition of tumor inception in the crown-gall disease with the use of ribonuclease A. Proceedings of the National Academy of Sciences of the United States of America 56, I417-I422.

Britten, R. J. \& Kohne, D. E. (1965). Nucleotide sequence repetition in DNA. Carnegie Institution o Washington Yearbook 65, 78-106.

Chilton, M. D., Currier, T. C., Farrand, S. K., Gordon, M. P., Bendich, A. J. \& Nester, E. W. (1974a). Attempts to detect Agrobacterium tumefaciens DNA in crown gall tumor DNA by renaturation kinetic analysis. Abstracts of the Annual Meeting American Society of Microbiologists, p. 162.

Chilton, M. D., Currier, T. C., Farrand, S. K., Bendich, A. J., Gordon, M. P. \& Nester, E. W. $(1974 b)$. Agrobacterium tumefaciens DNA and PS8 bacteriophage DNA not detected in crown gall tumors. Proceedings of the National Academy of Sciences of the United States of America 7r, 3672-3676.

Clowes, R. C. \& HAYEs, W. (1968). Experiments in Microbial Genetics, pp. I84-185. New York: John Wiley.

DENHARDT, D. T. (1966). A membrane-filter technique for the detection of complementary DNA. Biochemical and Biophysical Research Communications 23, 64I-646.

DrlicA, K. A. \& KaDO, C. I. (1974). Quantitative estimation of Agrobacterium tumefaciens DNA in crown gall tumor cells. Proceedings of the National Academy of Sciences of the United States of America 7r, 3677-368I.

Eden, F. C., Farrand, S. K., Powell, J. S., Bendich, A. J., Chilton, M., Nester, E. W. \& Gordon, M. P. (1974). Attempts to detect deoxyribonucleic acid from Agrobacterium tumefaciens and bacteriophage PS8 in crown gall tumors by complementary ribonucleic acid/deoxyribonucleic acid filterhybridization. Journal of Bacteriology $119,547-553$.

Guerry, P., LeBlanc, D. J. \& Falkow, S. (1973). General method for the isolation of plasmid deoxyribonucleic acids. Journal of Bacteriology $116,1064-1066$.

Guille, E., QưETIER, F. \& Hugưt, T. (I968). Étude des acides désoxyribonucléiques des végétaux. Formation d'un $A D N$ nucléaire riche en $\mathbf{G}+\mathbf{C}$ iors de la blessure de certaines plantes supérieures. Comptes rendus hebdomadaire des séances de l'Académie des sciences 266, 836-838.

KIRBY, K. S. (1957). Isolation of deoxyribonucleic acid. Biochemical Journal 66, 495-503.

Kohler, R. E., Ron, E. Z. \& Davis, B. D. (1966). Polysomes extracted from Escherichia coli by freezethaw-lysozyme lysis. Science, New York 153, I I 19-1 120.

MARMUR, J. (196I). A procedure for the isolation of deoxyribonucleic acid from micro-organisms. Journal of Molecular Biology 3, 208-218.

McConaughy, B. L. \& MCCARThy, B. J. (1967). The interaction of oligodeoxynucleotides with denatured DNA. Biochimica et biophysica acta 149, I80-189.

Milo, G. E. \& SRIVASTAVA, B. I. S. (1969). RNA-DNA hybridization studies with the crown gall bacteria and the tobacco tumor tissue. Biochemical and Biophysical Research Communications 34, 196-199.

Prensky, W., Steffensen, De M. \& Hughes, W. L. (1973). Use of iodinated RNA for gene localization. Proceedings of the National Academy of Sciences of the United States of America 70, I860-1864.

Quetier, F., HugueT, T. \& Guille, E. (1969). Induction of crown-gall: partial homology between tumorcell DNA, bacterial DNA and the G + C-rich DNA of stressed normal cells. Biochemical and Biophysical Research Communications 34, $128-133$. 
SChilperoort, R. A., VAn Sittert, N. J. \& Schell, J. (I973). The presence of both phage PS8 and Agrobacterium tumefaciens A6 DNA base sequences in A6-induced sterile crown-gall tissue cultured in vitro. European Journal of Biochemistry 33, $\mathrm{I}-7$.

Schilperoort, R. A., Veldstra, H., Warnaar, S. O., Mulder, G. \& Cohen, J. A. (1967). Formation of complexes between DNA isolation from tobacco crown gall tumors and RNA complementary to Agrobacterium tumefaciens DNA. Biochimica et biophysica acta 145, 523-525.

Sharp, P. A., Pettersson, U. \& Sambrook, J. (1974). Viral DNA in transformed cells. I. A study of the sequences of adenovirus 2 DNA in a line of transformed rat cells using specific fragments of the viral genome. Journal of Molecular Biology 86, 709-726.

SRIVASTAVA, B. I. S. (1965). Studies on nucleic acids from healthy and tumerous tomato stem tissue. Biochimica et biophysica acta 103, 349-352.

VAn Larebeke, N., Engler, G., Holsters, M., Van der Elsacker, S., Zaenen, I., Schilperoort, R. A. \& SCHELl, J. (1974). Large plasmid in Agrobacterium tumefaciens essential for crown gall-inducing ability. Nature, London 252, 169-1 70.

WetMUR, J. G. \& DAvidson, N. (I968). Kinetics of renaturation of DNA. Journal of Molecular Biology 31, 349-370.

Wood, H. N. \& Braun, A. C. (I961). Studies on the regulation of certain essential biosynthetic systems in normal and crown-gall tumor cells. Proceedings of the National Academy of Sciences of the United States of America 47, 1907-1913.

Zaenen, I., Van Larebeke, N., Teuchy, H., Van Montagu, M. \& Schell, J. (1974). Supercoiled circular DNA in crown-gall inducing Agrobacterium strains. Journal of Molecular Biology 86, 109-127. 